\title{
CD4 Expressing T Cell Count
}

National Cancer Institute

\section{Source}

National Cancer Institute. CD4 Expressing T Cell Count. NCI Thesaurus. Code C74608.

The determination of the number of CD4 expressing T cells present in a sample. 